\title{
Pengaruh Pendidikan dan Pelatihan (DIKLAT) terhadap Kinerja Pegawai Negeri Sipil pada Kantor Dinas Pendidikan dan Kebudayaan Kabupaten Batang Hari
}

\author{
Etty Siswati" ${ }^{*}$ Evi Fauzani, Riado Houlion Sinaga \\ Sekolah Tinggi Ilmu Ekonomi Graha Karya, Muara Bulian \\ ${ }^{*}$ Correspondence email: ettysiswati793@gmail.com
}

\begin{abstract}
Abstrak. Penelitian ini bertujuan untuk mengetahui pengaruh Pendidikan dan Pelatihan (diklat) terhadap Kinerja Pegawai Negeri Sipil pada Kantor Dinas Pendidikan dan Kebudayaan Kabupaten Batanghari. Penelitian ini termasuk penelitian deskriptif kuantitatif. Sampel penelitian ini adalah 56 orang. Berdasarkan hasil dari Uji parsial (Uji t). Diperoleh nilai thitung untuk (X) Pendidikan dan Pelatihan (diklat) sebesar 6.626 dan nilai dari tabel sebesar 1.67303 karena nilai thitung lebih besar dari nilai tabel maka dapat disimpulkan bahwa Pendidikan dan Pelatihan (diklat) berpengaruh signifikan terhadap kinerja pegawai Negeri Sipil pada Kantor Dinas Pendidikan dan Kebudayaan Kabupaten Batanghari. Berdasarkan Hasil dari Koofesien Determinasi R Square sebesar 0,448. Jadi dapat disimpulkan bahwa presentase pengaruh variabel Pendidikan dan pelatihan $(\mathrm{X})$ terhadap variabel Kinerja Pegawai Negeri Sipil pada Dinas Pendidikan dan Kebudayaan Di Kabupaten Batanghari sebesar 0,448 atau sebesar 44,8\% dan sisanya 55,2\% dipengaruhi oleh variabel lain yang tidak diteliti dalam penelitian ini.
\end{abstract}

Kata Kunci: Pendidikan dan pelatihan; Kinerja Pegawai Negeri Sipil

Abstract. This study aims to determine the effect of education and training on the performance of civil servants Kantor Dinas Pendidikan dan Kebudayaan Kabupaten Batanghari. This research is a descriptive quantitative research. The sample of this research is 56 people. Based on the results of the partial test ( $t$ test). Obtained tcount value for $(X)$ Education and Training (Diklat) is 6.626 and the value of ttable is 1.67303 because the tcount value is greater than the ttable value, it can be concluded that Education and Training (education and training) has a significant effect on the performance of civil servants in Kantor Dinas Pendidikan dan Kebudayaan Kabupaten Batanghari. Based on the results of the R Square determination coefficient of 0.448. So it can be concluded that the percentage effect of the Education and Training $(X)$ variable on the Civil Servant Performance variable on Dinas Pendidikan dan Kebudayaan Kabupaten Batanghari amounting to 0.448 or $44.8 \%$ and the remaining $55.2 \%$ is influenced by other variables not examined in this study

Keywords: Education and training; Performance of Civil Servants

\section{PENDAHULUAN}

Sumber daya manusia merupakan salah satu komponen yang ada dalam organisasi selain machine, material, methods and market. Setiap instansi harus di dukung sumber daya manusia yang benar karena sumber daya manusia sangat berperan dalam menjalankan usaha atau kegiatan di dalam instansi tersebut. Sumber daya manusia merupakan faktor penggerak yang menentukan hasil akhir dari proses pembangunan nasional suatu bangsa. Sumber daya manusia yang diharapkan adalah beriman, bertaqwa,mampu menjaga amanat, cerdas dan memiliki etos kerja yang produktif, berwawasan ilmu pengetahuan dan teknologi serta peduli terhadap lingkungan. Pegawai negeri sipil sebagai sumber daya manusia yang berkompeten memegang peranan sangat penting yang tujuannya memaksimalkan kinerja yang dimiliknya. Dalam artiannya, kinerja menjadi hal yang penting untuk diperhatikan organisasi, karna dapat mempengaruhi tercapainya tujuan organisasi dalam menghadapi persaingan global yang sering berubah. Menurut Adella et al (2006), berpendapat bahwa kinerja adalah melakukan suatu kegiatan dan menyempurnakannya sesuai tanggung jawabnya dengan hasil seperti yang diharapkan.

Pentingnya pendidikan dan pelatihan (diklat) merupakan amanat Undang-undang dimana dalam undang-undang nomor 43 tahun 1999 tentang perubahan atas undang-undang nomor 8 tahun 1974 tentang pokok-pokok kepegawaian pasal 31 ayat 1 disebutkan bahwa" Untuk mencapai daya guna dan hasil guna yang sebenarnya diadakan pengaturan dan penyelenggaraan pendidikan dan pelatihan jabatan pegawai negeri sipil yang bertujuan untuk meningkatkan pengabdian, mutu, keahlian, kemampuan dan keterampilan. Berdasarkan pasal tersebut dapat dijelaskan bahwa pendidikan dan pelatihan pegawai negeri sipil pada dasarnya untuk meningkatkan profesionalisme yang mengarah kepada keberhasilan tugas secara efektif dan efisien. Pendidikan dan pelatihan merupakan salah satu bentuk pembinaan terhadap pegawai negeri sipil untuk menambah pengetahuan dan keterampilan sehingga dapat mengikuti perkembangan, perubahan sistem dan teknologi dalam menjalankan tugas yang dibebankan kepadanya. 
Kantor Dinas Pendidikan dan Kebudayaan merupakan salah satu kantor yang ada di Kabupaten Batanghari,dimana jumlah pegawai yang berstatus pegawai negeri sipil (PNS) sebanyak 56 orang. Berdasarkan pengamatan penulis, ada banyak pelatihan yang telah diikuti oleh pagawai yang ada di kantor Dinas Pendidikan dan Kebudayaan Kabupaten Batanghari baik itu pelatihan di dalam lingkup kabupaten Batanghari atau pun yang di adakan oleh negara dalam hal ini pelatihan yang diikuti oleh pegawai instansi pemerintah yang diadakan oleh pemerintah pusat

\section{METODE}

Populasi menurut Sugiyono (2016) adalah wilayah generalisasi yang terdiri atas obyek atau subyek yang mempunyai kualitas dan karakteristik tertentu yang ditetapkan oleh peneliti untuk dipelajari dan kemudian ditarik kesimpulannya. Populasi yang diambil dari penelitian ini adalah seluruh Pegawai Negeri Sipil (PNS) pada Dinas Pendidikan dan Kebudayaan Kabupaten Batang Hari sebanyak 56 orang. Sampel menurut Sugiyono (2016) adalah sebagian dari jumlah dan karakteristik yang dimiliki oleh populasi tersebut. Sampel merupakan sebagian wakil dari populasi yang diteliti. Apabila populasi penelitian berjumlah kurang dari 100 maka sampel yang diambil adalah semuanya. Dalam penelitian ini dikarenakan populasi hanya berjumlah 56 orang, maka peneliti menjadikan semuanya sebagai sampel penelitian. Sampel yang akan diambil dalam penelitian ini semua Pegawai Negeri Sipil (PNS) pada Dinas Pendidikan dan Kebudayaan Kabupaten Batang Hari sebanyak 56 orang.

\section{Metode Analisis}

Deskripsi penelitian ini yaitu mengumpulkan data sebanyak-banyaknya dari hasil penelitian untuk menjelaskan maksud dan tujuan dari penelitian ini, maka metode penelitian yang dipakai dalam penelitian ini yaitu deskriptif-kuantitatif. Menurut Sugiyono (2016) deskriptif-kuantitatif dapat diartikan sebagai metode penelitian yang berdasarkan pada filsafat positivisme, digunakan untuk meneliti pada populasi dan sampel tertentu. Metode ini digunakan untuk menjelaskan pengaruh Pendidikan dan Pelatihan (diklat) terhadap Kierja Pegawai Negeri Sipil di Kantor Dinas Pendidikan dan Kebudayaan Kabupaten Batanghari Metode analisis yang dipakai dalam penelitan ini yaitu menggunakan metode sebagai berikut:

\section{Skala Likert}

Tabel 1. Penilaian Bobot Jawaban Responden

\begin{tabular}{cc}
\hline Pilihan Jawaban & Skor \\
\hline Sangat Tidak Setuju & 1 \\
Tidak Setuju & 2 \\
Cukup Setuju & 3 \\
Setuju & 4 \\
Sangat Setuju & 5 \\
\hline
\end{tabular}

Sumber: Sugiyono (2016)
Setelah itu digunakan rentang skala dalam penelitian ini yang disesuaikan dengan penggunaan Skala Likert yaitu:

$$
\begin{aligned}
\text { Skala Likert } & =\frac{(\text { NilaiTertinggi-NilaiTerendah })}{5} \\
& =\frac{(5-1)}{5}=0,8
\end{aligned}
$$

Tabel 2. Indeks Penilaian Jawaban Responden

\begin{tabular}{cc}
\hline Nilai Indeks & Penilaian \\
\hline $1<\mathrm{x} \leq 1,8$ & Sangat Tidak Baik \\
$1,8<\mathrm{x} \leq 2,6$ & Tidak Baik \\
$2,6<\mathrm{x} \leq 3,4$ & Cukup Baik \\
$3,4<\mathrm{x} \leq 4,2$ & Baik \\
$4,2<\mathrm{x} \leq 5$ & Sangat Baik \\
\hline
\end{tabular}

Sumber: Sugiyono (2016)

\section{Methode Suceceaive Interval (MSI)}

Methode Succesive Interval (MSI) merupakan metode yang digunakan untuk mentransformasikan data dari ordinal menjadi interval. Dimana variabel bebas $X$ Pendidikaan dan Pelatihan dengan variabel terikat $\mathrm{Y}$ (Kinerja Pegawai) yang dikumpulkan oleh peneliti melalui kuesioner masih memiliki skala ordinal, dengan Methode Succesive Interval (MSI) data yang memiliki skala ordinal tadi ditransformasikan menjadi data interval. Riduwan dan Kuncoro (2011) yang dikutip oleh Giska Anggia Putri (2015) didalam jurnalnya, menyatakan mentransformasikan data interval bertujuan untuk memenuhi sebagian dari syarat analisis parametrik, dimana data setidaknya berskala interval.

\section{Uji Kualitas Data Uji validitas}

Uji validitas adalah untuk mengetahui tingkat validitas dari instrumen kuesioner yang digunakan dalam pengumpulan data uji validitas ini dilakukan untuk mengetahui apakah item-item yang tersaji dalam kuesioner benar-benar mampu mengungkapkan dengan pasti apa yang akan diteliti. Menurut Sugiyono (2016) syarat minimum untuk dianggap valid adalah nilai $r_{\text {hitung }}$ $>$ dari nilai $r_{\text {tabel. }}$ Validitas alat ukur diuji dengan menghitung korelasi antara nilai yang diperoleh dari setiap butir pernyataan dengan keseluruhan yang diperoleh pada alat ukur tersebut. Metode yang digunakan adalah product moment.

\section{Uji Reliability}

Sedangkan uji reliabilitas dimaksudkan untuk adanya konsisten alat ukur dalam penggunaannya atau dengan kata lain alat ukur tersebut mempunyai hasil yang konsisten apabila digunakan berkali-kali pada waktu yang berbeda Sugiyono (2016). Untuk mengetahui kestabilan dan konsistensi responden dalam menjawab pernyataan dalam suatu kuesioner. Untuk pengujian reliabilitas instrument dilakukan dengan 
tehnik cronbach's Alpha kriteria penilaian uji reliabilitas adalah sebagai berikut:

1. Apabila hasil cronbach's Alpha lebih besar dari taraf signifikan $50 \%$ atau 0,5 maka kuesioner reliabel.

2. Apabila hasil cronbach's Alpha lebih kecil dari taraf signifikan 50\% atau 0,5 maka kuesioner tersebut tidak reliabel.

\section{Alat Analisis Regresi Linear Sederhana}

Analisis regresi linear berganda digunakan untuk mengukur kekuatan hubungan antara dua variabel atau lebih, juga menunjukkan arah hubungan antara varaiabel dependen dengan independen. Berdasarkan permasalahan, alat analisis statistika yang menggunakan analisis regresi berganda, sehingga teknis analisis yang digunakan dalam penelitian ini adalah sebagai berikut Sugiyono (2016) :

$\mathbf{Y}=\mathbf{a}+\mathbf{b X}$

Dimana: $\mathrm{Y}=$ Kinerja Karyawan; $\alpha=$ Konstanta; $\mathrm{b}=$ Koefesien regresi; $\mathrm{X}=$ Pendidikan dan Pelatihan; dan $\mathrm{e}=$ error

\section{Uji Parsial (Uji t)}

Uji t digunakan untuk menunjukkan seberapa jauh pengaruh variabel independen / bebas secara parsial dalam menerangkan variasi variabel dependen/terikat. Menurut Sugiyono (2016) kriteria pengambilan keputusan dilakukan dengan cara membandingkan $t_{\text {hitung }}$ dengan tabel.

\section{Koefisien Determinasi}

Setelah diperoleh nilai koefisien korelasi, langkah selanjutnya adalah mencari nilai koefisien determinasi $\left(\mathrm{R}^{2}\right)$ yang merupakan kuadrat dari koefisien korelasi $(\mathrm{R})$. Koefisien determinasi digunakan untuk mengukur sejauh mana kemampuan model dalam menerangkan variasi variabel terikat (dependen). Menurut Sugiyono (2016) koefisien determinasi dihitung dengan mengkuadratkan koefisien korelasi yang telah ditemukan dan dikalikan dengan $100 \%$. Nilai koefisien determinasi adalah antara nol sampai satu. Semakin kecil nila $\mathrm{R}^{2}$ berarti kemampuan variabel-variabel independen/bebas dalam menejelaskan variabel dependen/terikat terbatas, sedangkan koefisien determinasi yang semakin mendekati nilai satu menunjukkan semakin kuatnya kemampuan dalam menjelaskan perubahan variabel bebas terhadap variasi variabel terikat sehingga mendekati sempurna.

\section{HASIL DAN PEMBAHASAN Uji Validitas}

Tabel 3. Uji Validitas

\begin{tabular}{|l|l|l|l|l|}
\hline No & Item & r hitung & r Tabel & Keterangan \\
\hline \multicolumn{5}{|l|}{ Varibel X } \\
\hline 1 & P1 & 0,710 & 0,2586 & Valid \\
\hline 2 & P2 & 0,716 & 0,2586 & Valid \\
\hline 3 & P3 & 0,655 & 0,2586 & Valid \\
\hline 4 & P4 & 0,712 & 0,2586 & Valid \\
\hline 5 & P5 & 0,705 & 0,2586 & Valid \\
\hline 6 & P5 & 0,694 & 0,2586 & Valid \\
\hline \multicolumn{5}{|l|}{ Variabel Y } \\
\hline 1 & P1 & 0,637 & 0,2586 & Valid \\
\hline 2 & P2 & 0,710 & 0,2586 & Valid \\
\hline 3 & P3 & 0,277 & 0,2586 & Valid \\
\hline 4 & P4 & 0,692 & 0,2586 & Valid \\
\hline 5 & P5 & 0,679 & 0,2586 & Valid \\
\hline 6 & P6 & 0,661 & 0,2586 & Valid \\
\hline
\end{tabular}

Sumber: Data diolah

Tabel 3 menunjukan bahwa semua indikator yang digunaka untuk menukur variabel variabel pada penelitian ini memiliki korelasi yang lebih besar dari $\mathrm{r}_{\text {tabel }}(0,2586)$. Jadi dapat disimpulkan indikator tersebut valid.

\section{Uji Reliability}

Perhitungan pada Uji reliabilitas ini juga mengunakan program SPSS 20. Hasil perhitungan lalu dibandingkan dengan tingkat signifika sebesar $50 \%$ $(0,05)$. Berdasarkan hasil dapat diketahui bahwa keseluruhan variabel memiliki nilai cronbach's alpha lebih besa $(>)$ dari tingkat signifikan. Hal ini bahwa keseluruhan variabel dinyatakan reliabel untuk ditetapakan dalam penelitian ini.

Tabel 4. Reliability Statistics

\begin{tabular}{|l|l|c|c|c|}
\hline No & Variabel Penelitian & Cronbach's Alpha & Tingkat Signifikan & Keterangan \\
\hline 1 & Pendidikan dan Pelatihan (diklat) & 0,843 & 0,05 & Reliabel \\
\hline 2 & Kinerja Pegawai & 0,802 & 0,05 & Reliabel \\
\hline
\end{tabular}

Sumber: Data diolah

Berdasarkan dari tabel diatas dapat diketahui bahwa keseluruhan variabel memiliki nilai cronbach's alpha lebih besar (>) dari tingkat signifikan. 
Etty Siswati, Evi Fauzani dan Riado Houlion Sinaga, Pengaruh Pendidikan dan Pelatihan (DIKLAT) terhadap Kinerja Pegawai Negeri Sipil pada Kantor Dinas Pendidikan dan Kebudayaan Kabupaten Batang Hari

\section{Hasil Regresi Linear Sederhana}

Tabel 5. Coefficients ${ }^{\mathrm{a}}$

\begin{tabular}{|l|l|r|r|r|r|r|r|}
\hline \multicolumn{2}{|l|}{ Model } & \multicolumn{2}{|c|}{ Unstandardized Coefficients } & Standardized Coefficients & \multirow{2}{*}{ Sig. } & \\
\cline { 3 - 7 } \multicolumn{2}{l|}{1} & B & Std. Error & Beta & & & \\
\hline \multirow{2}{*}{1} & (Constant) & 8.772 & 2.493 & .001 \\
\cline { 2 - 8 } & Pendidikan dan Pelatihan & .661 & .100 & .670 & 6.626 & .000 \\
\hline
\end{tabular}

Sumber: data olahan

Berdasarkan tabel diatas dapat di peroleh rumusan regresi sebagai berikut:

1. $\mathrm{a}=8.772$

Artinya apabila variabel Pendidikan dan Pelatihan maka variabel kinerja pegawai adalah sebesar 8.772.

2. Pendidikan dan Pelatihan $=0,661$.

Nilai coefficients untuk variabel Pendidikan dan Pelatihan (X) adalah 0,661 Hal ini menunjukan bahwa setiap kenaikan variabel Kinerja Pegawai naik sebesar satu satuan maka variabel Kinerja Pegawai (X) di Kantor Pendidikan dan Kebudayaan Kabupaten Batanghari akan naik sebesar 0.661.

\section{Uji Parsial (Uji t)}

Dalam penelitian ini juga menggunakan bantuan SPSS versi 20.0 yang mana hasil uji t juga dapat dilihat pada tabel diatas (Coefficients). Diuji dengan tingkat signifikan sebesar 0,05\%, df $\mathrm{n}-\mathrm{k}-1$ maka $56-1-1=$ $54(\mathrm{t}$ Tabel $=1.67303)$ pada tabel Coefficients di atas, didapatlah $t_{\text {tabel }}$ sebesar dari $t_{\text {hitung }}$ atau $(6.626>1.67303)$ maka Ho di terima. Kesimpuln adalah Variabel Pendidikan dan Pelatiian berpengaruh signifikan terhadap variabel Kinerja Pegawai di Kantor Pendidikan dan Kebudayaan Kabupaten Batanghari

\section{Koefisien Determinasi $\left(\mathbf{R}^{2}\right)$}

Uji koefisien determinasi ini bertujuan untuk mengetahui seberapa besar presentase variabel Pendidikan dan Pelatihan (X), terhadap variabel Kinerja Pegawai (Y) untuk melihat nilai koefisien determinasi dapat dilihat pada tabel dibawah ini :

Tabel 6. Model Summary

\begin{tabular}{|l|r|r|r|r|}
\hline Model & R & R Square & Adjusted R Square & \multicolumn{1}{c|}{ Std. Error of the Estimate } \\
\hline 1 & $.670^{\mathrm{a}}$ & .448 & .438 & 1.83432 \\
\hline
\end{tabular}

Sumber: data olahan

Tabel model summary diatas dapat dilihat bahwa nilai $\mathrm{R}$ Square sebesar 0,448. Jadi dapat disimpulkan bahwa presentase pengaruh variabel Pendidikan dan pelatihan $(\mathrm{X})$,) terhadap variabel Kinerja Pegawai karyawan pada Dinas pendidikan dan Kebudayaan Di Kabupaten Batanghari sebesar 0,448 atau sebesar 44,8\% dan sisanya 55,2 \% dipengaruhi oleh variabel lain yang tidak diteliti dalam penelitian ini.

\section{SIMPULAN}

Diuji dengan tingkat signifikan sebesar $0,05 \%$,df $\mathrm{n}-\mathrm{k}-1$ maka $56-1-1=54(\mathrm{t}$ Tabel $=1.67303)$ pada tabel Coefficients di atas, didapatlah $t_{\text {tabel }}$ sebesar dari

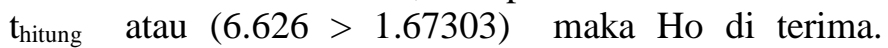
Kesimpuln adalah Variabel Pendidikan dan Pelatiian berpengaruh signifikan terhadap variabel Kinerja Pegawai di Kantor Pendidikan dan Kebudayaan Kabupaten Batanghari. Persentase pengaruh variabel Pendidikan dan pelatihan (X)) terhadap variabel Kinerja Pegawai karyawan pada Dinas pendidikan dan Kebudayaan Di Kabupaten Batanghari sebesar 0,448 atau sebesar 44,8\% dan sisanya 55,2 \% dipengaruhi oleh variabel lain yang tidak diteliti dalam penelitian ini.

\section{DAFTAR PUSTAKA}

Adella. HS, Heni Nastiti, Dwi Widodo (2009),Pengaruh Disiplin, Komunikasi Dan Motivasi Terhadap Kinerja JOURNAL Manajemen Volume 8, Nomor 1,Januari 2009, Halaman41-52, ISSN 1421-5021

Giska Anggia Putri, Susi Hendriani, Chairul Amsal PENGARUH REKRUTMEN DAN PELATIHAN TERHADAP KINERJA KARYAWAN PADA PT. SAMUDRA OCEANEERING BATAM Vol 2, No 1 (2015)

Riduwan \& Kuncoro. 2011. Cara Menggunakan dan Memakai Path Analysis (Analisis Jalur). Bandung: Alfabeta

Sugiyono. 2016. Metode Penelitian Kuantitaif Kualitatif dan $R \& B$, Bandung: Alfabeta

Undang-undang nomor 43 Tahun 1999 tentang Pokokpokok Kepegawaian

Undang-undang nomor 8 Tahun 1974 tentang Pokokpokok Kepegawaian 